\title{
Fine structure of neurosecretory cells and sinus gland in the eyestalk of the freshwater crab Travancoriana schirnerae Bott, 1969 (Decapoda: Gecarcinucidae)
}

\section{Sudha Devi Arath Raghavan ${ }^{1, *}$, Aswani Ayanath ${ }^{1}$ and Bhadravathi Kenchappa Chandrasekhar Sagar ${ }^{2}$}

${ }^{1}$ Department of Zoology. Mary Matha Arts \& Science College. Wayanad. Kerala 670 645, India.*E-mail: arsudhadevi@gmail.com.

${ }^{2}$ Department of Neuropathology. National Institute of Mental Health and Neurosciences. Bangalore. Karnataka 560 029. India.

\begin{abstract}
This study elucidated the fine structure of neurosecretory cells and sinus gland in the optic ganglia of the freshwater crab Travancoriana schirnerae Bott, 1969 (Decapoda: Gecarcinucidae). The eyestalk ganglion showed the presence of four well defined ganglia arranged below the ommatidium: lamina ganglionaris, medulla externa, medulla interna and medulla terminalis of which the lamina ganglionaris, was devoid of neurosecretory cells. Groups of neurosecretory cells seen distributed along the medulla externa, interna and terminalis regions constitute the X-organs. Electron microscopic observations of the eyestalk ganglia revealed ten types of neurosecretory cells, mostly apolar with a few unipolar and bipolar cells classified according to the size, shape and density of the cell and nucleus, cell organelles/inclusions, together with the arrangement and properties of chromatin. These cells were characterized by the presence of large nuclei with unusually condensed chromatin, inclusions like vacuoles and vesicles of varying size, shape and density and organelles like Golgi, endoplasmic reticulum, ribosomes and mitochondria and neurosecretory material. The sinus gland of T. schirnerae was positioned laterally between the externa and interna regions, composed of axonal endings of the neurosecretory cells of the optic ganglia with interspersed glial cells. The axon terminals were enclosed with several small to large membrane bound homogenously dense neurosecretory granules which also occur in the preterminal areas of the axons. Based on size, shape and density of granules and axoplasmic matrix, seven terminal types could be distinguished in the sinus gland of T. schirnerae. Mostly, the granules contained in a terminal were of the same type; rarely, the same terminal enclosed granules of varying size, shape and density. The neurosecretory cell types and axon terminal types represent the types of neurohormones they contained. A precise knowledge of the morphology and cytology
\end{abstract}

Received

August 30, 2019

Accepted

December 15, 2019

Released

December 31, 2019

Full Text Article

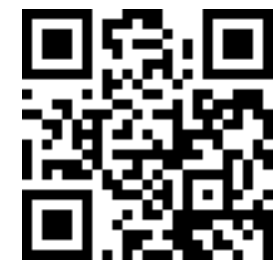

\footnotetext{
ORCID

(D) 0000-0003-4062-8073 Sudha Devi Arath Raghavan

(D) 0000-0003-4184-6734 Aswani Ayanath

D 0000-0002-7043-8767

Bhadravathi

Kenchappa

Chandrasekhar Sagar
} 
of neurosecretory cells in the XO-SG complex of the eyestalk that secrete neurohormones controlling major physiological processes such as growth and reproduction is imperative for successful captive breeding of a species of aquaculture potential.

Keywords: Eyestalk; Freshwater crab; Neurosecretory cells; Sinus gland; Travancoriana schirnerae.

\section{Introduction}

The optic ganglion in the eyestalk of decapod crustaceans is an important source of hormones that control major physiological processes such as growth and reproduction (Bliss and Welsh, 1952; Knowles, 1955; Knowles and Carlisle, 1956; Matsumoto, 1958). Upadhyaya (2000) divided the optic ganglia into four parts: lamina ganglionaris, medulla externa, interna and terminalis, of which the lamina ganglionaris region is devoid of neurosecretory cells (NSC). The NSCs observed in groups on medulla externa, interna and terminalis regions are termed as medulla externa $\mathrm{X}$ organ (ME-XO), medulla interna $\mathrm{X}$ organ (MI-XO) and medulla terminalis $\mathrm{X}$ organ (MT-XO). Neurosecretory granules (NSG) synthesized in cell bodies of these NSCs are transported via their axons to axon terminals. The axonal endings from NSCs of the optic ganglia, brain and thoracic ganglia together with interspersed glial cells constitute the sinus gland (SG), a neurohemal organ concerned with the storage and release of a number of neurohormones like the moult inhibiting hormone, gonad inhibiting hormone, crustacean hyperglycemic hormone, retinal pigment concentrating hormone and pigment dispersing hormone that regulate important physiological processes like moult and growth, gonad development, blood sugar level, colour change, tegumentary and retinal pigment position, secondary sexual characterristics, locomotion and neuronal activity (Knowles and Carlisle, 1956; Carlisle and Knowles, 1959; Naylor et al., 1973; Beltz, 1988; Mohamed and Diwan, 1991;
Fingerman et al., 1993; Charmantier et al., 1997).

Several light and electron microscopic studies have been made to describe the $\mathrm{X}$ organ-sinus gland (XO-SG) system of brachyurans (Bliss and Welsh, 1952; Matsumoto, 1954; Parameswaran, 1956; Durand, 1956; Potter, 1954; Smith, 1974; Andrew et al., 1978; Dircksen, 1992). Enami (1951) classified the NSCs in the brain of the crab Sesarma. Lake (1970) has made substantial contributions to the studies on the NSCs types in the crab Paragrapsus gaimardii. Studies on the neurosecretory centres of the eyestalk and their involvement in moulting and reproduction have been carried out in Carcinus maenas by Smith (1975). Hisano (1974) detailed the light and electron microscopic studies of the NSCs types in the optic ganglia of the prawn Palaemon paucidens. Van Herp et al. (1977) made light microscopic study of the eyestalk NSCs of Palaemon serratus. Andrew et al. (1978) evaluated the structure of NSCs in the crayfish eyestalk. Bharathi et al. (2014) made a comparative study of NSCs in female Penaeus indicus after unilateral eyestalk ablation. Pandey et al. (2015) described the histomorphological changes in NSCs of eyestalk, brain and thoracic ganglia in the flower tail shrimp Metapenaeus dobsoni during different stages of ovarian maturation. Rajendiran and Vasudevan (2016) focused on the histological mapping of NSCs and the identification of possible sites of crustacean hyperglycemic hormone immunoreactivity in the optic ganglia of Portunus pelagicus. Though sufficient information is available on morphology, cytology and distribution of the NSC types in the optic 
ganglia, brain and abdominal ganglia (Enami, 1951; Durand, 1956; Matsumoto, 1954; Potter, 1958) and SG of marine decapods (Charmantier-Daures and Segonzac, 1998, Andrews et al., 1971), limited work has been attempted on freshwater brachyurans (Diwan and Nagabhushanam, 1975). Moreover, the crab species mentioned in this study, widely distributed in the wetlands of Wayanad, is edible and forms a cheap source of animal protein for the malnourished local tribes. A precise knowledge of the morphology and cytology of neurosecretory cells in the XO-SG complex of the eyestalk that secrete neurohormones controlling major physiological processes such as growth and reproduction is imperative for successful captive breeding of a species of aquaculture potential. In this perspective, the present work on fine structural analysis of the NSCs and SG found in the optic ganglia of Travancoriana schirnerae is undertaken.

\section{Methodology}

Adult intermoult crabs (carapace width $4.5-5 \mathrm{~cm}$ ) collected from the paddy fields of Ondayangadi, Wayanad $\left(11^{\circ} 49^{\prime} 20.3^{\prime \prime} \mathrm{N}\right.$ and $\left.76^{\circ} 01^{\prime} 47.1^{\prime \prime} \mathrm{E}\right)$ were allowed to acclimatize to the laboratory environment for a few days. They were fed with cooked beef liver, pulses and decaying aquatic vegetation. The wet weight, carapace width and moult stage of the animals were recorded before ablating the eyestalks. The eyestalks were carefully excised under a Trinocular stereo zoom dissection microscope and frozen for $24 \mathrm{hrs}$. The optic ganglia were dissected out by removing the exoskeleton using fine scissors and needles.

For ultrastructural studies, the tissues were fixed in 3\% Glutaraldehyde in $0.1 \mathrm{M}$ phosphate buffer ( $\mathrm{pH}$ 7.2) for $24 \mathrm{~h}$, washed twice in the same buffer, postfixed in $1 \%$ osmium tetroxide for 90 minutes and dehydrated in graded ethanol series. After clearing in propylene oxide, the tissue was left in a mixture of propylene oxide and araldite resin (1:1) overnight, then increased to $1: 3$ ratio followed by pure araldite resin for 2-3 $\mathrm{h}$. Tissues were then embedded in flat embedding moulds and kept in an oven at $60^{\circ} \mathrm{C}$ for $48 \mathrm{~h}$ for polymerization (Frasca and Parks, 1965).

Once the polymerization completed, semithin sections of $0.5 \mu \mathrm{m}$ thickness were cut under a UC 7 Ultramicrotome (Leica Microsystems, Germany), stained with $1 \%$ toluidine blue and observed under a Leica DM 500 Research Microscope with Dewinter camera attachment and Biowizard software for light microscopic observations. For ultrastructural studies, $60 \mathrm{~nm}$ thick sections were cut and stained with uranyl acetate followed by lead citrate. Stained sections were mounted on copper grids and scanned under a JEM 1400 Plus Transmission Electron Microscope (JEOL, Japan) operating at $60 \mathrm{KV}$. Selected regions were captured using a Gatan SC 1000B CCD camera and the electron micrographs were analyzed for fine structural details.

\section{Results}

\section{Light microscopy}

The longitudinal section of eyestalk ganglion of $T$. schirnerae showed the presence of four well defined ganglia arranged below the ommatidium: lamina ganglionaris (LG), medulla externa (ME), medulla interna (MI) and medulla terminalis (MT), of which the topmost or distal portion is the LG, devoid of neurosecretory cells (NSCs) (Figure 1A). Below the LG is the ME and the proximal region of the optic ganglion is the MT which tapers to form the optic nerve. Medulla interna is located between the $\mathrm{ME}$ and MT regions. Groups of NSCs were seen distributed along the ME, MI and $\mathrm{MT}$ regions constitute the $\mathrm{X}$-organs (XO). The NSCs located dorsolaterally and at the surface between the LG and ME constitute the ME-XO while those 
observed laterally in the MI as well as the MT regions constitute the MI-XO and MT$\mathrm{XO}$, respectively.

Light microscopic observations revealed seven types of NSCs in the Xorgans of optic ganglia: type I, II, III, IV, V, VI and VII based on size and shape of the nucleus as well as the arrangement of chromatin. Frequency distribution of the cell types is given in Table 1. Maximum number of NSCs were found in ME-XO region and minimum in MT-XO. Type I were the most abundant cell types (36\%) noticed in ME-XO followed by Type $\mathrm{V}$
(24\%), VI (19\%), IV (11\%), VII (4\%), II and III (3\% each). MT-XO showed less number of cells with all the seven types. The abundance was in the order type I, V, VII, II, IV, VI and III. Type I was the most abundant cells in MI-XO followed by type V, IV, III, VI, II and VII (Figures 1B-D).

The SG of T. schirnerae appeared as a deeply stained oval structure, located laterally between the ME and MI (Figure 1E). Light microscopic observations revealed the presence of numerous highly basophilic round or oval bodies, called the axon terminals.
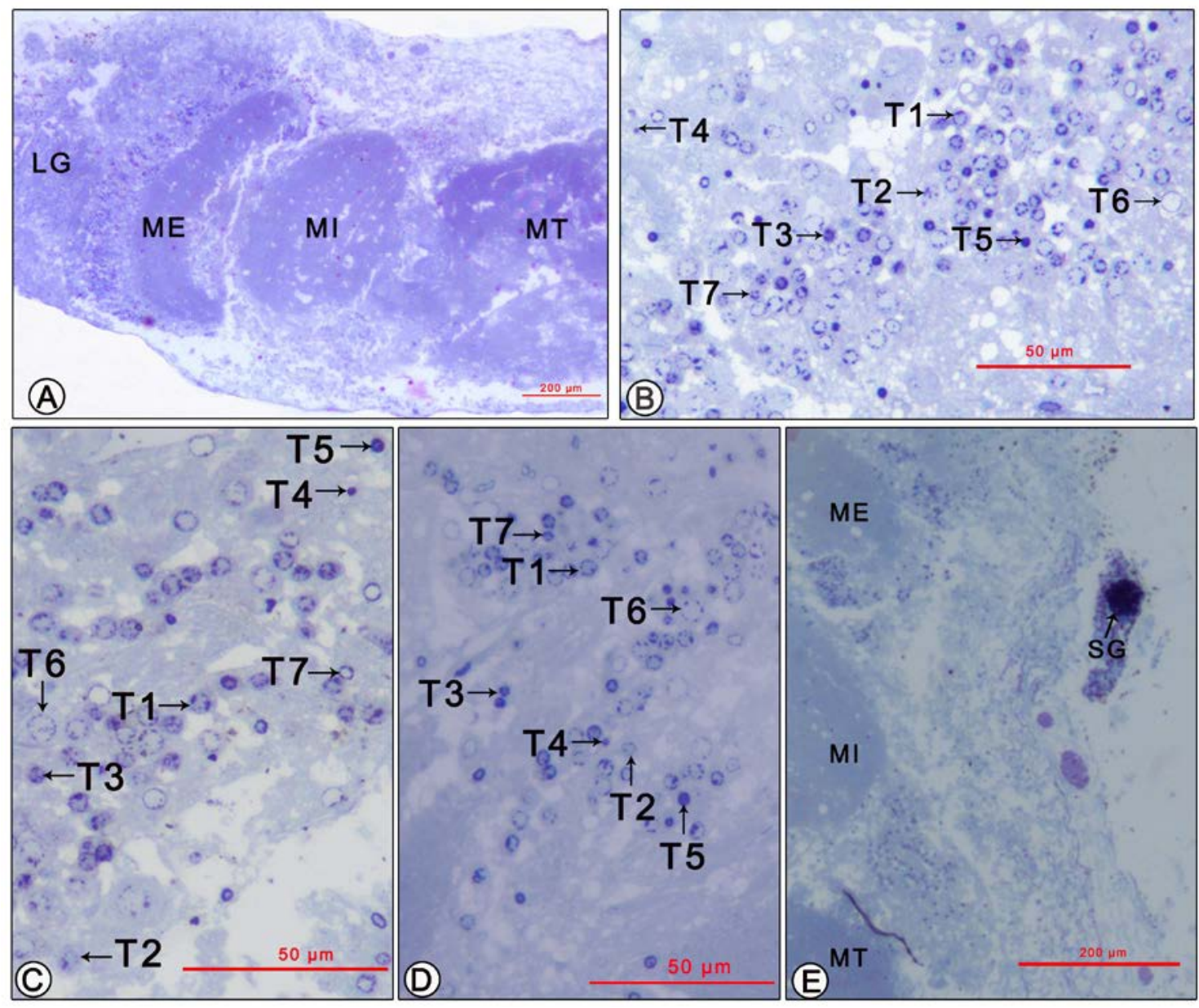

Figure 1. Light micrographs of eyestalk ganglia of intermoult T. schirnerae showing various ganglionic regions, neurosecretory cells types and the sinus gland. (A) Eyestalk ganglia demonstrating lamina ganglionaris, medulla externa, interna and terminalis regions (B-D) Neurosecretory cells of ME-XO, MI-XO and MT-XO regions (E) Sinus gland between ME and MI regions. LG: Lamina ganglionaris; ME: Medulla externa; MI: Medulla interna; MT: Medulla terminalis; SG: Sinus gland; T1: Type 1; T2: Type 2; T3: Type 3; T4: Type 4; T5: Type 5; T6: Type 6; T7: Type 7 
Table 1. Frequency distribution of cell types in the ME-XO, MI-XO and MT-XO regions of the optic ganglion in T. schirnerae.

\begin{tabular}{|l|c|c|c|}
\hline Type of NSC & ME-XO & MI-XO & MT-XO \\
\hline I & $265(36 \%)$ & $56(38 \%)$ & $32(43 \%)$ \\
\hline II & $23(03 \%)$ & $8(05 \%)$ & $7(10 \%)$ \\
\hline III & $23(03 \%)$ & $11(08 \%)$ & $4(05 \%)$ \\
\hline IV & $81(11 \%)$ & $27(12 \%)$ & $6(08 \%)$ \\
\hline V & $176(24 \%)$ & $38(26 \%)$ & $11(15 \%)$ \\
\hline VI & $141(19 \%)$ & $9(06 \%)$ & $6(08 \%)$ \\
\hline VII & $26(04 \%)$ & $8(05 \%)$ & $8(11 \%)$ \\
\hline
\end{tabular}

\section{Ultrastructure}

Electron micrographs of the eyestalk ganglia showed ten types of NSCs namely type I, II, III, IV, V, VI, VII, VIII, IX and X, classified according to the size, shape, electron density of the cell and nucleus, cell organelles/inclusions, together with the arrangement and properties of chromatin. The NSCs were characterized by the presence of nuclei with unusually dense chromatin, inclusions like vacuoles and vesicles of varying size, shape and density and organelles like Golgi, endoplasmic reticulum (ER), ribosomes, mitochondria and neurosecretory granules (NSG). The NSCs found in the eyestalk ganglia of $T$. schirnerae were mostly apolar (Type II, III, IV, V, IX and X) with a few unipolar (Type I, VI and VII) and bipolar cells (Type VIII).

\section{Type I}

Round or irregular, unipolar cells, measured 6.33-8.00 $\mu \mathrm{m}$ diameter with large electron lucent nuclei (4.67-5.33 $\mu \mathrm{m})$. The nucleocytoplasmic ratio (NPR) was found in the range 0.58-0.84. Besides forming strong dense irregular blocks at the periphery of the nucleus, the chromatin was seen as small dense granules scattered throughout the nucleoplasm. The moderately dense cytoplasm was characterized by the presence of a large number of vesicles and vacuoles of varying size, shape and density: clear vesicles (membrane bound vesicles measuring 0.12-0.45 $\mu \mathrm{m}$ diameter), condensing vesicles (membrane bound vesicles filled with a dense homogenous ground substance, 0.40-0.48 $\mu \mathrm{m}$ in diameter) and autophagic vacuoles $(0.80-0.83 \mu \mathrm{m})$ with cell debris. Fine electron dense NSGs (0.02-0.04 $\mu \mathrm{m})$ were seen distributed in clusters throughout the cytoplasm. Besides these inclusions, the cytoplasm contained organelles like mitochondria (width 0.31-0.39 $\mu \mathrm{m}$ ) with moderately dense matrix and parallel cristae, cisternae and vesicles (0.04-0.10 $\mu \mathrm{m}$ diameter) of Golgi and rough endoplasmic reticulum (RER) cisternae (0.02-0.03 $\mu \mathrm{m}$ width) (Figures 2A-B).

\section{Type II}

Rectangular cell bodies with a size range of 4.67-7.79 $\mu \mathrm{m}$. Nuclei were elongate or oval with wavy margins and measured 2.67-5.17 $\mu \mathrm{m}$ across. In addition to the small electron dense granules which fill the nucleoplasm, dense blocks of chromatin were perceptible towards the periphery. These cells were distinguished with a NPR of 0.57 to 0.66 . The moderately dense cytoplasm contained clear vesicles $(0.29$ $0.69 \mu \mathrm{m})$, condensing vesicles $(0.34-0.87$ $\mu \mathrm{m})$, autophagic vacuoles (0.41-0.93 $\mu \mathrm{m})$, multivesicular bodies (MVB) (0.48-0.54 $\mu \mathrm{m}$ ), clusters of moderately dense NSGs (0.05-0.08 $\mu \mathrm{m})$ in proximity to Golgi vesicles, mitochondria (0.58-1.22 $\mu \mathrm{m})$ with irregular or poor fragmented cristae and scattered ER cisternae (0.06-0.12 $\mu \mathrm{m}$ width) (Figure 2C). 

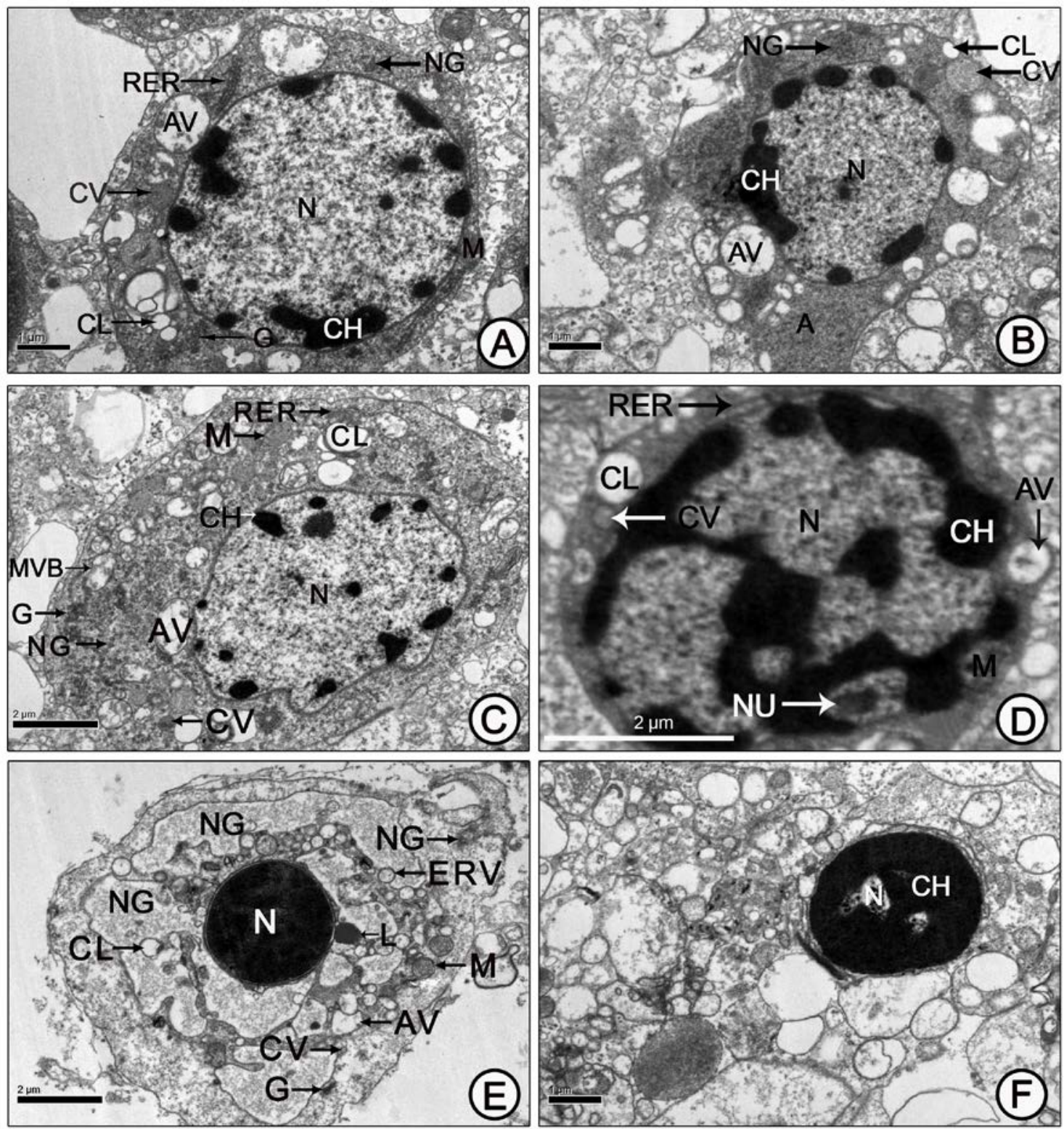

Figure 2. Electron micrographs showing type I to $\mathrm{V}$ neurosecretory cells in the optic ganglion of $T$. schirnerae. (A-B) Type I neurosecretory cell (C-D) Type II and III neurosecretory cells accommodating various organelles and inclusion bodies (E) Perikarya of type IV cell depicting various types of vesicles, vacuoles and cell organelles (F) Type V cells with dense nuclei. A: Axon; AV: Autophagic vacuole; CH: Chromatin; CL: Clear vesicle; CV: Condensing vesicle; ERV: ER bound vesicle; G: Golgi vesicles; L: Lysosome; M: Mitochondria; MVB: Multivesicular body; N: Nucleus; NG: Neurosecretory granules; NU: Nucleolus; RER: Rough endoplasmic reticulum.

\section{Type III}

Round or irregularly shaped cells (3.61-6.67 $\mu \mathrm{m})$, filled with moderately dense cytoplasm carrying oval to elongate, large, medium dense nuclei (2.68-4.67 $\mu \mathrm{m})$. A remarkable feature noticed was their high NPR (0.70-0.74). The strongly dense chromatin forms a ring at the periphery and small blocks of chromatin were seen scattered in the nucleoplasm. The nucleoplasm has dense granulations and uninucleolated, with 
the nucleoli $(0.3 \mu \mathrm{m})$ occupying peripheral positions. The perikaryon accommodated inclusions like clear vesicles (0.12-0.48 $\mu \mathrm{m}$ in diameter), condensing vesicles (0.23-0.45 $\mu \mathrm{m})$, autophagic vacuoles $(0.28-1.9 \mu \mathrm{m}$ in diameter) packed with cell debris, scattered NSGs $(0.05-0.06 \mu \mathrm{m})$ and organelles like a few mitochondria (0.46$0.53 \mu \mathrm{m}$ across) having irregular or fragmented cristae and scattered cisternae of RER (0.04-0.08 $\mu \mathrm{m}$ thick) (Figure 2D).

\section{Type IV}

Larger cells $\quad(8.0-8.08 \quad \mu \mathrm{m}$ diameter) with small, round or spherical nuclei $(2.87-3.30 \mu \mathrm{m})$ and large amount of cytoplasm. The NPR observed was low (0.36-0.41). The entire nucleoplasm was uniformly filled with an unusually dense chromatin. The cytoplasm enclosed many large, irregular-shaped membrane bound vesicles filled with electron lucent coarse granules (NSGs 0.05-0.06 $\mu \mathrm{m}$ ), clear vesicles $(0.20-0.55 \mu \mathrm{m}), \quad$ ER bound vesicles $(0.10-0.30 \mu \mathrm{m})$, condensing vesicles $(0.10-0.4 \mu \mathrm{m})$, autophagic vacuoles (0.15-0.45 $\mu \mathrm{m})$ along with a few moderately dense mitochondria $(0.5$ $0.65 \mu \mathrm{m}$ ) having irregular cristae, Golgi vesicles $(0.05-0.07 \mu \mathrm{m})$ with moderate or dense contents and lysosomes (0.21-0.65 $\mu \mathrm{m}$ diameter) (Figure 2E).

\section{Type $\mathbf{V}$}

Round or oval cells with wavy margins (2.84-4.67 $\mu \mathrm{m} \quad$ width), characterized by large round or oval nuclei $(2.52-3.53 \mu \mathrm{m})$ and negligible amounts of cytoplasm (NPR 0.75-0.89 $\mu \mathrm{m})$. The nucleoplasm was partially or fully occupied by strongly dense chromatin. In partially dense nuclei, the core accommodates dense granules (Figure 2F).

\section{Type VI}

Unipolar cells $\quad$ 5.0-5.55 $\mu \mathrm{m}$ diameter) with large oval nuclei (4.5$5.16 \mu \mathrm{m})$ and small amounts of cytoplasm (NPR 0.90-0.93). The dense chromatin forms a ring attached to the inner nuclear membrane. Along with clear vesicles $(0.26-0.60 \mu \mathrm{m})$, a few round or oval mitochondria (0.26-0.71 $\mu \mathrm{m})$ with poor cristae were discernible in the perikarya. The axonal region contained numerous moderate to dense NSGs (0.03-0.04 $\mu \mathrm{m})$, vesicles with granular contents, autophagic vacuoles (0.13-0.23 $\mu \mathrm{m})$ and a few MVBs $(0.52 \mu \mathrm{m}$ across) (Figures 3A-B).

\section{Type VII}

Oval to elongate (3.57-5.16 $\mu \mathrm{m}$ across), unipolar cells possessing elongate nuclei (3.07-4.29 $\mu \mathrm{m})$ with wavy margins (NPR 0.79-0.83). Besides the dense blocks seen attached to the inner nuclear membrane, dense granules of chromatin were found strewn in the nucleoplasm. The cytoplasm enclosed scattered NSGs, clear vesicles (0.125-1.0 $\mu \mathrm{m})$, condensing vesicles $(0.25-0.37 \mu \mathrm{m})$, autophagic vacuoles $(0.41-0.83 \mu \mathrm{m})$ and stacks of cisternae of RER (0.04-0.03 $\mu \mathrm{m})$. Neurosecretory granules $(0.04-0.06$ $\mu \mathrm{m})$ and ER bound vesicles (0.41-0.50 $\mu \mathrm{m})$ were also noticed in the axonal region (Figure 3C). 

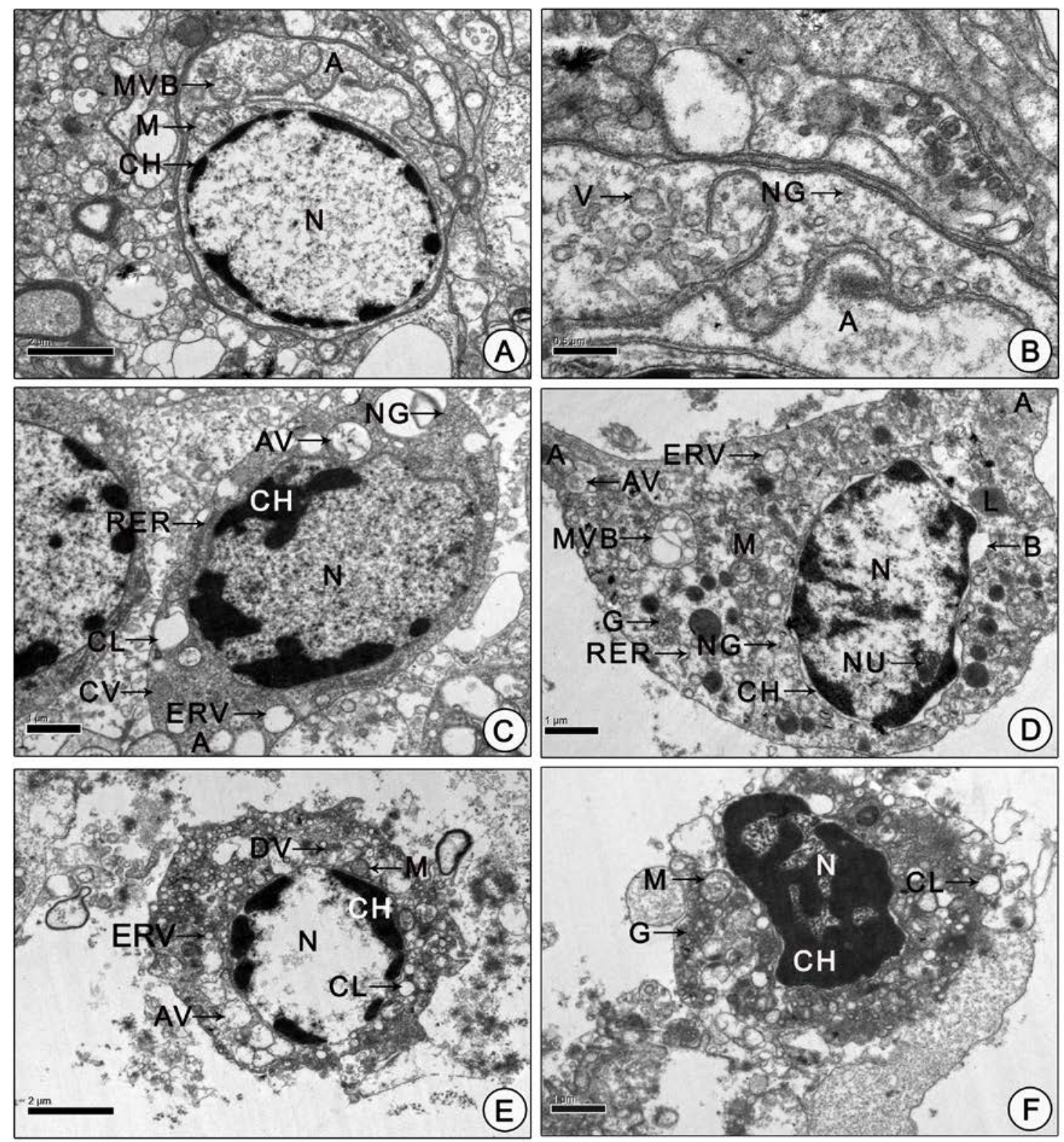

Figure 3. Electron micrographs of Type VI, VII, VIII, IX and X neurosecretory cells in the optic ganglion of T. schirnerae. (A) Unipolar Type VI neurosecretory cell with large nucleus and sparse cytoplasm (B) Axon of type VI cell enclosing vesicles and neurosecretory granules (C) Unipolar Type VII cells with large irregular blocks of chromatin, various types of vesicles and autophagic vacuoles in the perikarya (D) Large bipolar type VIII cell with blebbing of outer nuclear envelope, neurosecretory granules and lysosomes (E) Type IX neurosecretory cell with clumps of dense chromatin bordering the nucleus with transparent core area (F) Type X cells with numerous vesicles and unusually dense chromatin. A: Axon; AV: Autophagic vacuole; B: Nuclear blebbing; $\mathrm{CH}$ : Chromatin; CL: Clear vesicle; CV: Condensing vesicle; DV: Dense core vesicle; ERV: ER bound vesicle; G: Golgi vesicles; L: Lysosome; M: Mitochondria; MVB: Multivesicular bodies; N: Nucleus; NG: Neurosecretory granules; NU: Nucleolus; RER: Rough Endoplasmic reticulum; V: Vesicle. 


\section{Type VIII}

Large, triangular shaped, bipolar cells (width 8.40-8.57 $\mu \mathrm{m}$ ) possessing oval to elongate nuclei (width 3.0-3.28 $\mu \mathrm{m})$ with distinct nucleoli. The nucleus was seen pushed to one side of the cell and showed blebbing of the outer nuclear membrane (0.12-0.4 $\mu \mathrm{m})$. Patches of dense chromatin were arranged along the peripheral nucleoplasm. Autophagic vacuoles (0.12$0.36 \mu \mathrm{m}$ diameter), ER bound vesicles $(0.44 \mu \mathrm{m}), \quad$ MVBs $\quad(0.56-0.96 \mu \mathrm{m})$, mitochondria (0.36-0.68 $\mu \mathrm{m})$ with irregular or fragmented cristae, a few scattered RER cisternae (0.04-0.08 $\mu \mathrm{m}$ wide), clusters of Golgi vesicles (0.04$0.15 \mu \mathrm{m}$ in diameter) with lucent or moderately dense contents and small to large oval, membrane bound lysosomes with homogenous dense matrices $(0.2$ $0.52 \mu \mathrm{m}$ in diameter) and NSGs (0.04$0.06 \mu \mathrm{m}$ ) were apparent in the electron lucent cytoplasm. These cells were found to have low NPR (0.35-0.38) (Figure 3D).

\section{Type IX}

Oval to round cells (6.07-7.05 $\mu \mathrm{m}$ width) with irregular margins, possessing round, peripherally placed nuclei (3.64-4.27 $\mu \mathrm{m})$. Small clumps of dense chromatin border the circumference of the nucleus with transparent core area. These cells were usually noticed with a NPR of 0.59-0.61. The cytoplasm was characterized by an abundance of dense core vesicles $(0.10$ $0.16 \mu \mathrm{m}$ diameter), clear vesicles $(0.27-$ $0.38 \mu \mathrm{m})$, autophagic vacuoles (0.16-081 $\mu \mathrm{m}$ in diameter), ER bound vesicles (0.20-0.22 $\mu \mathrm{m})$, scattered NSGs (0.05$0.06 \mu \mathrm{m})$ and a few mitochondria (0.43$0.48 \mu \mathrm{m}$ ) with irregular or fragmented cristae (Figure 3E).

\section{Type X}

Oval cells with irregular margins (6.00-6.20 $\mu \mathrm{m}$ diameter). The nucleus (2.27-3.0 $\mu \mathrm{m}$ across) has an elongate or irregular shape with the strongly dense chromatin occupying almost the entire nucleoplasm with dense granular regions. Cytoplasm with moderate density enclosed numerous Golgi vesicles of varying sizes and densities, vacuoles (0.125-0.45 $\mu \mathrm{m})$ and mitochondria (0.50$0.58 \mu \mathrm{m}$ ) with poor cristae. These cells were observed with a low NPR (0.380.48) (Figure 3F).

In the optic ganglia of T. schirnerae, myelinations of axons were observed. The axolemma of the myelinated axons were surrounded by a dense cover called the microtubular sheath (0.4-0.60 $\mu \mathrm{m}$ thick). Outside the microtubular sheath is the myelin sheath, composed of bundles of myelin fibres which lie parallel to the longitudinal axis of the axon. The space between the microtubular sheath and the myelin sheath is the submyelinic space, filled with cytoplasm which forms numerous pseudopodia like projections. The submyelinic space contained organelles like mitochondria $(0.10-0.30 \mu \mathrm{m}$ width) and cisternae of RER (0.03-0.06 $\mu \mathrm{m}$ thick), condensing vesicles $(0.23-0.30$ $\mu \mathrm{m})$ and clear vesicles $(0.16-0.31 \mu \mathrm{m})$ (Figure 4D). Large blood sinuses and hemocytes -both granular (6.87-7.50 $\mu \mathrm{m})$ and agranular $(2.9-5.0 \mu \mathrm{m})$ were detected in the hemal sinuses of the eyestalk ganglia (Figure 4C).

\section{Non neurosecretory cells}

Large, rectangular electron lucent cells (8.67-11.50 $\mu \mathrm{m})$ arranged without intercellular spaces in the optic ganglia. The electron lucent nucleoplasm contained a few small patches of scattered chromatin. The cytoplasm contained organelles like oval to elongate, moderately dense mitochondria (0.5-1.0 $\mu \mathrm{m})$ with irregular cristae and dilated RER cisternae (0.15$0.94 \mu \mathrm{m}$ thick), but no inclusions like clear vesicles, condensing vesicles, autophagic vacuoles or NSGs which indicate their non-neurosecretory nature (Figure 4A). 
Table 2. Neurosecretory cells in the optic lobe of T. schirnerae.

\begin{tabular}{|c|c|c|c|c|c|c|}
\hline $\begin{array}{l}\text { Cell } \\
\text { type }\end{array}$ & $\begin{array}{c}\text { Cell size } \\
(\mu \mathrm{m}) / \text { shape }\end{array}$ & $\begin{array}{l}\text { Nucleus size } \\
(\mu \mathrm{m}) / \text { shape }\end{array}$ & NPR & $\begin{array}{l}\text { Nature of } \\
\text { chromatin }\end{array}$ & $\begin{array}{l}\text { Nature of } \\
\text { cytoplasm }\end{array}$ & $\begin{array}{c}\text { Cytoplasmic } \\
\text { inclusion/organell }\end{array}$ \\
\hline I & $\begin{array}{c}\text { 6.33-8.00 } \\
\text { unipolar, } \\
\text { round/irregul } \\
\text { ar }\end{array}$ & $\begin{array}{l}4.67-5.3 \\
\text { round to oval }\end{array}$ & $0.58-0.84$ & $\begin{array}{l}\text { strongly } \\
\text { dense, } \\
\text { irregular } \\
\text { blocks at the } \\
\text { periphery of } \\
\text { nucleus }\end{array}$ & $\begin{array}{l}\text { moderately } \\
\text { dense, } \\
\text { granular }\end{array}$ & $\begin{array}{c}\text { clear vesicles, } \\
\text { condensing vesicle, } \\
\text { autophagic vacuoles } \\
\text { and neurosecretory } \\
\text { granules (NSG) } \\
\text { mitochondria, Golgi } \\
\text { vesicles, RER } \\
\text { cisternae }\end{array}$ \\
\hline II & $\begin{array}{c}\text { 4.67-7.79 } \\
\text { rectangular }\end{array}$ & $\begin{array}{l}2.67-5.17 \\
\text { elongate/ } \\
\quad \text { oval }\end{array}$ & $0.57-0.66$ & $\begin{array}{l}\text { dense blocks } \\
\text { towards the } \\
\text { peripheral } \\
\text { nucleoplasm }\end{array}$ & $\begin{array}{l}\text { moderately } \\
\text { dense }\end{array}$ & $\begin{array}{c}\text { clear vesicles, } \\
\text { condensing vesicles, } \\
\text { autophagic vacuoles, } \\
\text { multivesicular bodies } \\
\text { (MVB), NSG } \\
\text { Golgi vesicles, } \\
\text { mitochondria, ER } \\
\text { cisternae }\end{array}$ \\
\hline III & $\begin{array}{l}\text { 3.61- } 6.67 \\
\text { round/oblong } \\
\text { /irregular }\end{array}$ & 2.68-4.67 oval & $0.70-0.74$ & $\begin{array}{c}\text { forms } \\
\text { strongly } \\
\text { dense ring at } \\
\text { the peripheral } \\
\text { nucleoplasm } \\
\text { and blocks } \\
\text { scattered in } \\
\text { the } \\
\text { nucleoplasm }\end{array}$ & $\begin{array}{l}\text { moderately } \\
\text { dense }\end{array}$ & $\begin{array}{l}\text { clear vesicles, } \\
\text { condensing vesicles, } \\
\text { autophagic vacuoles, } \\
\text { NSG } \\
\text { mitochondria, RER }\end{array}$ \\
\hline IV & $\begin{array}{l}8.0-8.08 \\
\text { irregular }\end{array}$ & $\begin{array}{l}2.87-3.30 \\
\text { spherical }\end{array}$ & $0.36-0.41$ & $\begin{array}{l}\text { unusually } \\
\text { dense, } \\
\text { uniformly fills } \\
\text { the entire } \\
\text { nucleoplasm }\end{array}$ & $\begin{array}{l}\text { electron } \\
\text { lucent }\end{array}$ & $\begin{array}{l}\text { clear vesicles, ER } \\
\text { bound vesicles, } \\
\text { condensing vesicles, } \\
\text { autophagic vacuoles } \\
\text { and NSG } \\
\text { mitochondria, Golgi } \\
\text { vesicles, lysosomes }\end{array}$ \\
\hline V & $\begin{array}{l}2.84-4.67 \\
\text { oval }\end{array}$ & $\begin{array}{l}2.52-3.53 \\
\text { round/oval }\end{array}$ & $0.75-0.89$ & $\begin{array}{l}\text { unusually } \\
\text { dense, fills } \\
\text { partially or } \\
\text { fully the } \\
\text { nucleoplasm } \\
\end{array}$ & $\begin{array}{l}\text { cytoplasm } \\
\text { negligible }\end{array}$ & - \\
\hline VI & $\begin{array}{c}5.00-5.55 \\
\text { unipolar, oval }\end{array}$ & $\begin{array}{c}4.50-5.16 \\
\text { Oval }\end{array}$ & $0.90-0.93$ & $\begin{array}{l}\text { dense blocks } \\
\text { attached to } \\
\text { inner nuclear } \\
\text { membrane }\end{array}$ & $\begin{array}{l}\text { electron } \\
\text { lucent }\end{array}$ & $\begin{array}{c}\text { clear vesicles, } \\
\text { autophagic vacuoles, } \\
\text { MVB and NSG } \\
\text { mitochondria }\end{array}$ \\
\hline VII & $\begin{array}{l}\text { 3.57-5.16 } \\
\text { unipolar oval } \\
\text { to elongate }\end{array}$ & $\begin{array}{c}\text { 3.07-4.29 } \\
\text { elongate with } \\
\text { wavy margins }\end{array}$ & $0.79-0.83$ & $\begin{array}{l}\text { forms dense } \\
\text { blocks } \\
\text { attached to } \\
\text { the inner } \\
\text { nuclear } \\
\text { membrane } \\
\text { and as } \\
\text { granules } \\
\text { strewn in the } \\
\text { nucleoplasm }\end{array}$ & $\begin{array}{l}\text { moderately } \\
\text { dense }\end{array}$ & $\begin{array}{c}\text { clear vesicles, } \\
\text { condensing vesicles, } \\
\text { autophagic vacuoles } \\
\text { and NSG } \\
\text { cisternae and vesicles } \\
\text { of RER }\end{array}$ \\
\hline VIII & $\begin{array}{l}8.4-8.57 \\
\text { bipolar, } \\
\text { triangular }\end{array}$ & $\begin{array}{l}3.0-3.28 \\
\text { Elongate }\end{array}$ & $0.35-0.38$ & $\begin{array}{l}\text { as patches } \\
\text { along the } \\
\text { peripheral } \\
\text { nucleoplasm. }\end{array}$ & $\begin{array}{l}\text { moderately } \\
\text { dense }\end{array}$ & $\begin{array}{l}\text { autophagic vacuoles, } \\
\text { MVB, NSG } \\
\text { mitochondria, } \\
\text { cisternae and vesicles } \\
\text { of RER, Golgi vesicles } \\
\text { and lysosomes }\end{array}$ \\
\hline
\end{tabular}


Table 2. Neurosecretory cells in the optic lobe of T. schirnerae.

\begin{tabular}{|c|c|c|c|c|c|c|}
\hline $\begin{array}{l}\text { Cell } \\
\text { type }\end{array}$ & $\begin{array}{c}\text { Cell size } \\
(\mu \mathrm{m}) / \text { shape }\end{array}$ & $\begin{array}{l}\text { Nucleus size } \\
(\mu \mathrm{m}) / \mathrm{sh} a p e\end{array}$ & NPR & $\begin{array}{l}\text { Nature of } \\
\text { chromatin }\end{array}$ & $\begin{array}{l}\text { Nature of } \\
\text { cytoplasm }\end{array}$ & $\begin{array}{c}\text { Cytoplasmic } \\
\text { inclusion/organell }\end{array}$ \\
\hline IX & $\begin{array}{c}\text { 6.07-7.05 } \\
\text { oval/irregular }\end{array}$ & $\begin{array}{l}3.64-4.27 \\
\text { round }\end{array}$ & $0.59-0.61$ & $\begin{array}{l}\text { dense ring } \\
\text { bordering the } \\
\text { circumference } \\
\text { of the nucleus }\end{array}$ & $\begin{array}{l}\text { moderately } \\
\text { dense }\end{array}$ & $\begin{array}{c}\text { dense core vesicles, } \\
\text { clear vesicles, } \\
\text { autophagic vacuoles } \\
\text { and NSG } \\
\text { ER bound vesicles } \\
\text { and mitochondria }\end{array}$ \\
\hline$X$ & $\begin{array}{l}\text { 6.00-6.2 } \\
\text { oval }\end{array}$ & $\begin{array}{l}2.27-3.0 \\
\text { Irregular }\end{array}$ & $0.38-0.48$ & $\begin{array}{c}\text { strongly } \\
\text { dense, } \\
\text { occupies } \\
\text { almost the } \\
\text { entire } \\
\text { nucleoplasm } \\
\text { with dense } \\
\text { granular } \\
\text { regions }\end{array}$ & $\begin{array}{l}\text { moderately } \\
\text { dense }\end{array}$ & $\begin{array}{l}\text { clear vesicles, } \\
\text { autophagic vacuoles } \\
\text { Golgi vesicles and } \\
\text { mitochondria }\end{array}$ \\
\hline
\end{tabular}
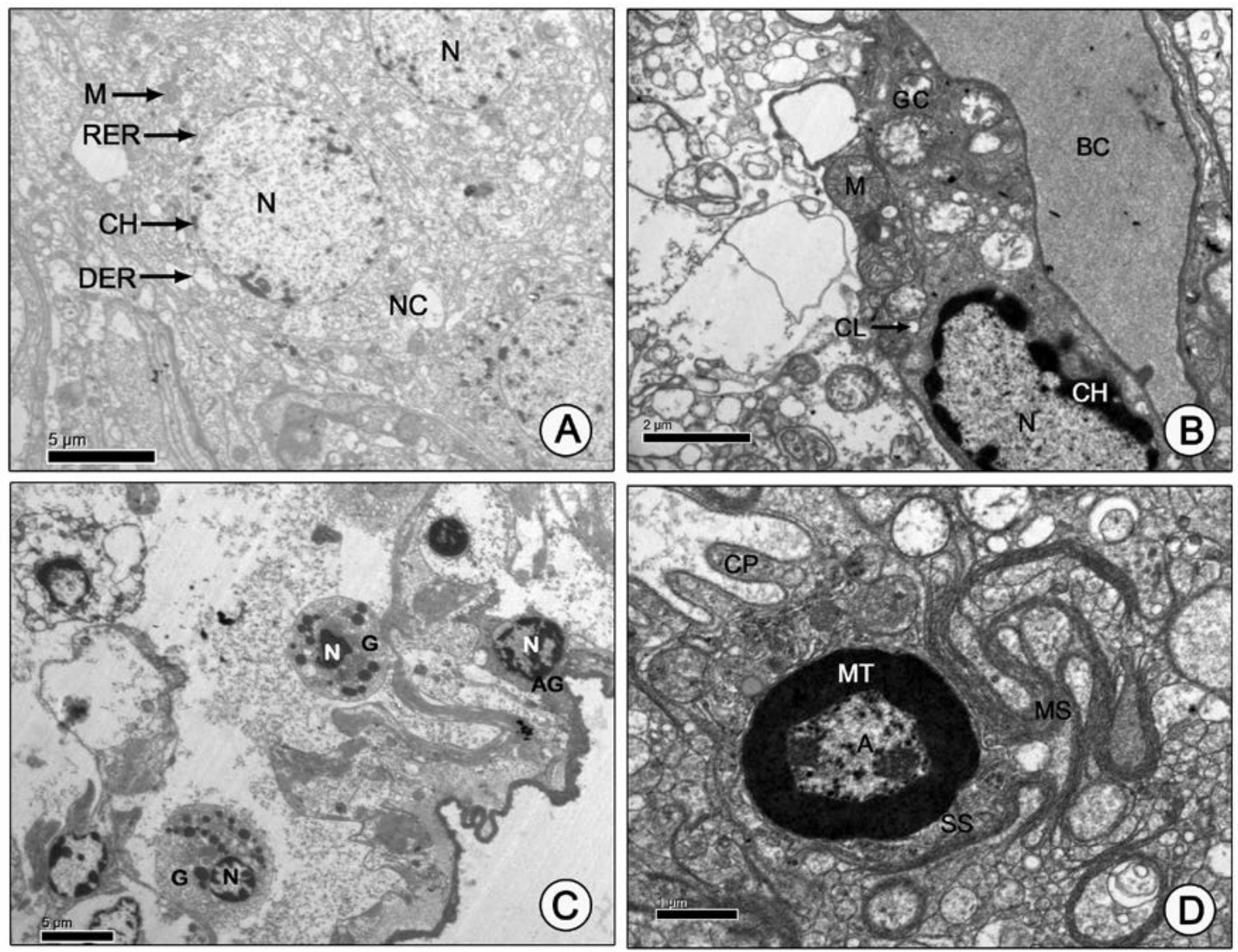

Figure 4. Electron micrographs illustrating non-neurosecretory cell, glial cell, axon of myelinated neuron, hemocytes and blood capillaries in the optic ganglion of T. schirnerae. (A-B) Glial cells (C) Granular and agranular hemocytes (D) Cross section of axon of myelinated neuron. A: Axon; AG: Agranulocytes; BC: Blood capillary; CH: Chromatin; CL: Clear vesicle; CP: Cytoplasmic process; DER: Dilated endoplasmic reticulum; G: Granulocytes; GC: Glial cell; M: Mitochondria; MS: Myelin sheath; MT: Microtubular sheath; N: Nucleus; NC: Non neurosecretory cell; RER: Rough endoplasmic reticulum; SS: Submyelinic space. 

gland

\section{Fine structure of the sinus}

The SG of T. schirnerae was positioned laterally between the ME and MI regions of the eyestalk ganglia. It is composed of axonal endings of the NSCs of the optic ganglia with interspersed glial cells. The axon terminals are enclosed with several large membrane bound homogenously dense NSGs which also occur in the preterminal areas of the axons. The axon terminals differ from each other in size, shape and density of granules and axoplasmic matrix. Mostly, the granules contained in a terminal were of the same type. Rarely, the same terminal enclosed granules of varying size, shape and density. Glial cells ramify between these terminals. Based on size, shape and density of granules contained, seven terminal types could be distinguished in the SG of T. schirnerae, designated as A1, A2, A3, A4, A5, A6 and A7 (Figures 5A-F) (Table 3).

Type A1 were irregular in shape (1.69-2.06 $\mu \mathrm{m}$ width), composed of numerous small sized, round, moderately dense granules (200-400 $\AA$ across). The A2 (3.21-4.66 $\mu \mathrm{m})$ terminals were irregular in outline containing small dense granules $(600-3300 \AA$ in diameter). Their axoplasm also included electron lucent vesicles $0.06-0.4 \mu \mathrm{m}$ in diameter) and concentric membranous lamellae. Type A3 were pear shaped, 2.77-3.07 $\mu \mathrm{m}$ in width, enclosing medium sized membrane bound homogenously dense round to oval granules (1500$3100 \AA$ in diameter). These were the second most abundant type which usually appeared in clusters. The oval to pear or irregular shaped A4 (2.77-4.31 $\mu \mathrm{m}$ across) were the most frequently encountered terminals, packed with large, oval to round, membrane bound, homogeneously dense granules with a diameter of 2300-6900 Å. Type A5 were mostly round or oval in outline (4.57$7.28 \mu \mathrm{m}$ across), accommodating small to large membrane bound, homogeneously dense granules (2800-7700 Å diameter). Often these granules have a shrunken appearance, characterized by a clear area between the dense core and the limiting membrane. Their axoplasm contained a few clear vesicles $(0.30-1.14 \mu \mathrm{m}$ in diameter) and concentric membranous

Table 3. Neurosecretory granules in the sinus gland of T. schirnerae.

\begin{tabular}{|c|c|c|c|c|c|}
\hline \multicolumn{3}{|c|}{ Axon terminal } & \multicolumn{3}{c|}{ Neurosecretory granules } \\
\hline Type & Size $(\boldsymbol{\mu m})$ & Shape & Size $(\boldsymbol{\mu m})$ & Shape & Nature \\
\hline 1 & $1.69-2.06$ & irregular & $0.02-0.04$ & round to oval & moderately dense \\
\hline 2 & $3.21-4.66$ & irregular & $0.06-0.33$ & small granules & highly dense \\
\hline 3 & $2.77-3.07$ & pear shaped & $0.15-0.31$ & round to oval & highly dense \\
\hline 4 & $2.77-4.31$ & $\begin{array}{c}\text { oval/ pear/ } \\
\text { irregular }\end{array}$ & $0.23-0.69$ & oval to round & $\begin{array}{c}\text { strongly dense, shrunken } \\
\text { appearance, clear area } \\
\text { between the dense core } \\
\text { and limiting membrane }\end{array}$ \\
\hline 5 & $4.57-7.28$ & round/oval & $0.28-0.77$ & oval to elongate & strongly dense \\
\hline 7 & $3.5-4.18$ & Round & $0.18-0.45$ & round or oval & strongly dense \\
\hline
\end{tabular}



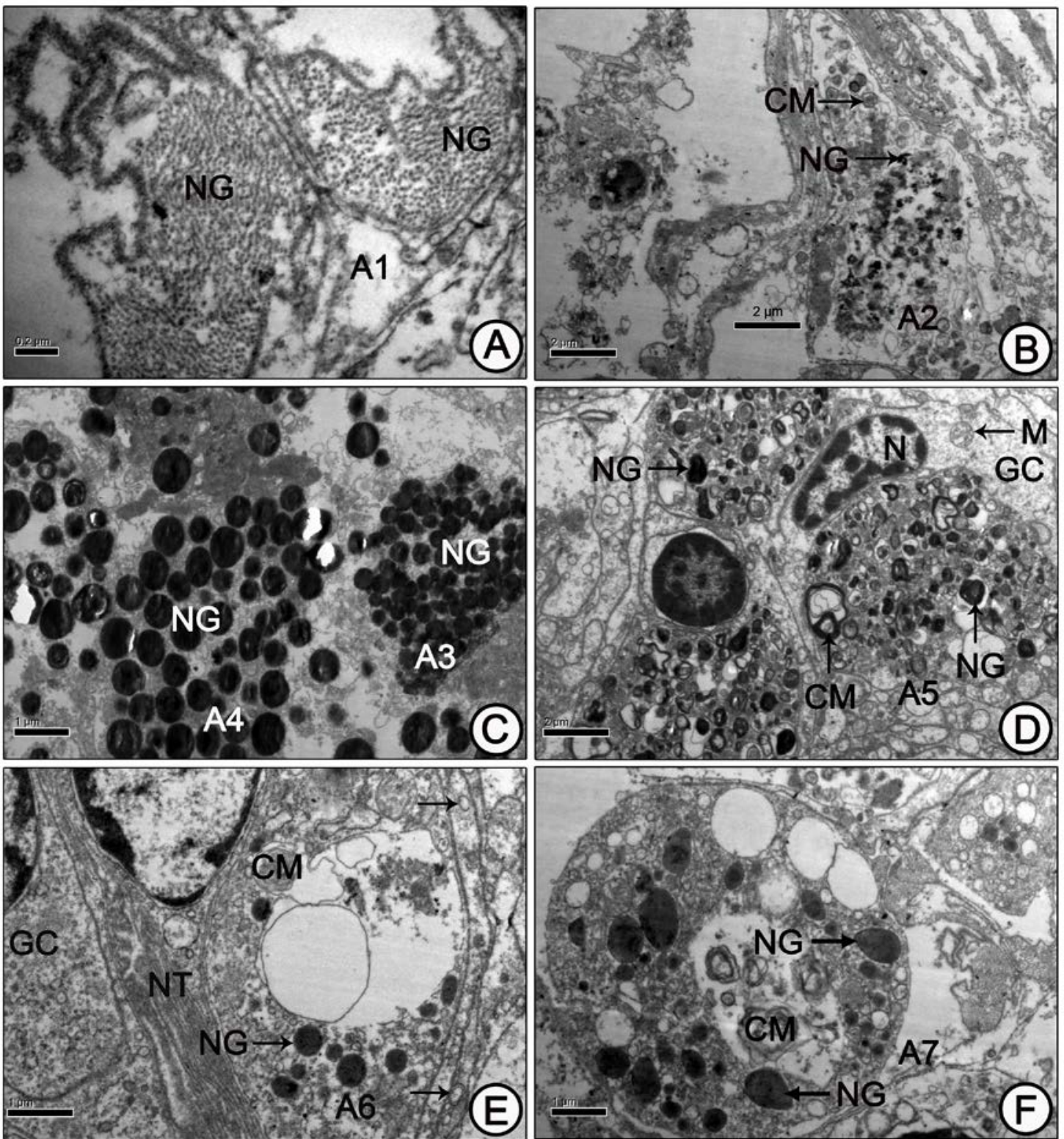

Figure 5. Ultra-thin sections of axon terminals in the sinus gland of T. schirnerae. (A-F) Axon terminals 1-7 enclosing various types of neurosecretory granules and inclusions in the sinus gland. Note the endocytotic invaginations of the axon terminal membrane in Figure E. A1: A1 axon terminal; A2: A2 axon terminal; A3: A3 axon terminal; A4: A4 axon terminal; A5: A5 axon terminal; A6: A6 axon terminal; A7: A7 axon terminal; CM: Concentric membrane; GC: Glial cell; M: Mitochondria; N: Nucleus; NG: Neurosecretory granules; NT: Neural tubules; Arrows indicate endocytotic invaginations of the axon terminal membrane.

lamellae. The A6 endings (3.5-4.18 $\mu \mathrm{m})$ were round with dense membrane bound granules with a size range of 1800-4500 $\AA$ and filled with a dense homogeneous substance containing small to large, round or oval electron lucent vesicles $(0.54-1.63 \mu \mathrm{m}$ in diameter) and concentric membranes. The A7 endings were spherical (2.15$5.16 \mu \mathrm{m}$ diameter) structures enclosing oval or pear shaped, membrane bound homogenously dense granules (0.07-0.71 $\mu \mathrm{m}$ in diameter). Their axoplasm enclosed numerous clear vesicles 0.15 - 
$0.31 \mu \mathrm{m}$ diameter) and concentric lamellae.

\section{Glial cells}

Were seen in the optic ganglia as well as in the SG intermingled with the axonal terminals. Elongate cells (2.63$6.84 \mu \mathrm{m}$ width) mostly with the nuclei (2.11-5.79 $\mu \mathrm{m}$ across) pushed to one half of the cell. Distinct nucleoli can be seen occupying central or peripheral positions in the nucleoplasm. The NPR measured was in the range 0.76-0.81. The dense chromatin was arranged as a peripheral thin rim or forms several blocks attached to the inner nuclear membrane. The cytoplasm accommodates ovoid mitochondria $\quad(0.40-0.95 \mu \mathrm{m})$ with irregular or fragmented cristae and clear vesicles (0.05-0.5 $\mu \mathrm{m}$ ) (Figure 4B). These cells send out several cytoplasmic processes called the glial cell processes which surround the axon terminals in the SG. These processes frequently enclosed mitochondria (0.25-0.63 $\mu \mathrm{m} \quad$ width), Golgi complexes, glycogen granules and dilated RER cisternae (Figures 6A-B).
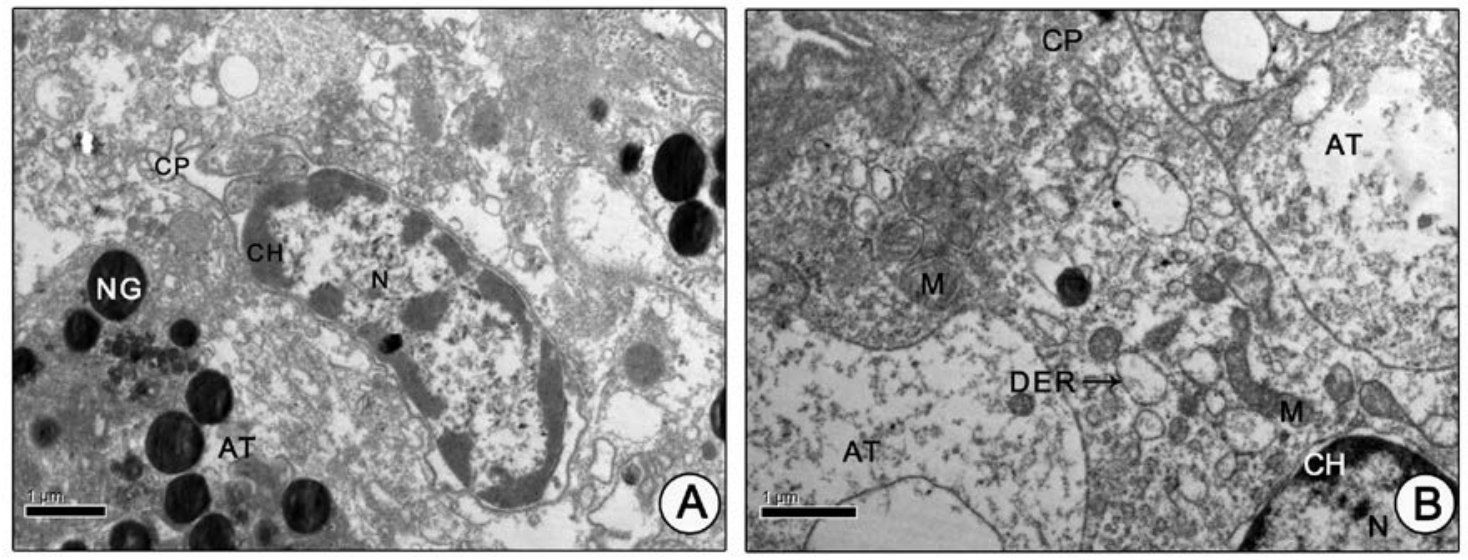

Figure 6. Glial cell and axon terminal in the sinus gland of T. schirnerae. (A) Glial cell nucleus interspersed among the axon terminals (B) Cytoplasmic processes of glial cell surrounding the axon terminal. AT: Axon terminal; $\mathrm{CH}$ : Chromatin; CP: Cytoplasmic process; DER: Dilated endoplasmic reticulum; M: Mitochondria; N: Nucleus; NG: Neurosecretory granule.

\section{Discussion}

Light and electron microscopic studies of the eyestalk of $T$. schirnerae revealed four ganglionic regions: the lamina ganglionaris, medulla externa, interna and terminalis along with the neurohaemal organ, the sinus gland. The microanatomy of the optic ganglia of $T$. schirnerae is identical to that of other crabs such as Eriocheir japonicus, Chionoecetes opilio, Potamon dehanni, Neptunus trituberculatus, Sesarma intermedia (Matsumoto, 1958), Diogenes bicristimanus (Nagabhushanam and sarojini, 1969); shrimps like $P$. indicus (Mohamed et al., 1993), Metapenaeus ensis, (Gunawardene et al., 2002) and the lobster Nephrops norvegicus (Giulianini et al., 1998; Fernandez and Radhakrishnan, 2010). Similar to the observations of the present study, many investigators reported the presence of three distinct X-organs: ME-XO, MI-XO and MT-XO in the eyestalks of Pandalus borealis (Carlisle, 1959), Macrobrachium rosenbergii (Dietz, 1982) and P. indicus (Mohamed et al., 1993). However, Hisano (1976) and Dietz (1982) have described only a single MI-XO complex in the optic ganglia of P.paucidens and 
M. rosenbergii. In P. japonicus (Nakamura, 1974) and P. serratus (Van Herp et al., 1977) the optic ganglia were observed without MI-XO.

The present study confirmed the presence of several neurosecretory cell types: seven light microscopically and ten ultrastructurally in the X-organs of the eyestalk ganglia. In agreement with these findings, many of the investigators have recognized diverse cell types in the eyestalks of crustaceans (Potter, 1958; Matsumoto, 1958): two in the lobster Thenus orientalis (Padmaja et al., 2010); three in crabs like Sesarma (Enami, 1951), Eriocheir sp. (Matsumoto, 1954) and Paratelphusa hydrodromous (Parameswaran, 1956) and prawn $P$. japonicus (Nakamura, 1974); four in the crayfish Orconectes virilis (Durand, 1956), shore crab P. gaimardii (Lake, 1970 ) and $P$. indicus (Bharathi et al., 2014) and five in P. borealis (Carlisle, 1959), P. serratus (Van Herp et al., 1977) and Parapenaeopsis stylifera (Nagabhushanam et al., 1986). Smith (1974, 1975), Fernandez and Radhakrishnan (2010) and Rajendiran and Vasudevan (2016) have categorized the NSCs into six distinct types in the optic ganglia of C. maenas, Panulirus homarus and $P$. pelagicus. Based on morphological variations in the elementary NSGs and RER, six peptidergic NSC types have been identified in the MT-XO region of the optic ganglia in $P$. paucidens (Hisano, 1976).

The current investigation evinced apolar, unipolar and bipolar NSCs in the optic ganglia of $T$. schirnerae. Large number of spherical apolar cells were evident in brachyurans and natantians (Matsumoto, 1954; Carlisle, 1953). On the other hand, Rajendiran and Vasudevan (2016) noticed tripolar and multipolar cells in addition to the unipolar and bipolar cells in the optic ganglia of $P$. pelagicus.

The NSCs in T. schirnerae were observed with organelles like Golgi bodies, mitochondria, ER, ribosomes and lysosomes and inclusions like clear vesicles, condensing vesicles, dense core vesicles, MVBs, autophagic vacuoles and NSGs in the perikarya. According to Fernandez and Radhakrishnan (2010), the cytoplasm of NSCs enclosed cell organelles like Golgi complex, mitochondria, ER, ribosomes, lysosomes and NSGs in $P$. homarus. Ultrastructurally, NSC bodies in the eyestalk of $C$. maenas displayed well developed Golgi bodies, parallel stacks of RER, MVBs, autophagic vacuoles, haloed dense cored vesicles and fine or coarse NSGs (Smith, 1975). Andrew et al. (1978) reported organelles like Golgi bodies, lysosomes and haloed dense core vesicles in $O$. virilis. Golgi cisternae, mitochondria, ER, MVBs, condensing vesicles and NSGs were reported in $P$. serratus (Bellon-Humbert et al., 1981). Hisano (1976) identified lysosomes in $P$. paucidens. Similar to the current study, NSGs were evident in Paratelphusa (Parameswaran, 1956), P. gaimardii (Lake, 1970) and $P$. indicus (Mohamed et al., 1993). The presence of Golgi complexes, mitochondria and ER in the NSCs of T. schirnerae corroborates their role in the synthesis of NSGs. The involvement of Golgi and mitochondria in the synthesis of neurosectretory material was established by Nishiitsutsuji-Uwo (1960) and Beams and Kessel (1968). It is stated that the RER, Golgi and vesicles are involved in the production, processing and storage of peptide hormones. The proteinaceous material synthesized in the ER is transported to the Golgi cisternae by the small vesicles. The presence of MVBs and lysosomes and their close association with NSGs in the NSCs of T. schirnerae is considered as a characteristic of active NSCs and suggest their role in degrading the neurosecretory material of the NSGs (Shivers, 1967). Lytic bodies and MVBs were characteristic of active neurosecretory cells in Gadus morrhua (Lederis, 1962), crayfish (Shivers, 1967) and the teleost pituitary (Hopkins, 1969). 
In agreement with the observations made by Hsu et al. (1980) and $\mathrm{Ke} \mathrm{Xu}$ and Terakawa (1999) in $P$. chinensis, the optic ganglia in $T$. schirnerae demonstrated the presence of myelinated axons with dense microtubular sheath, submyelinic space and myelin sheath surrounding the axolemma. Conversely, in Gecarcinus lateralis the axons of SG were nonmyelinated having thin limiting membranes (Hodge and Chapman, 1958). The myelin sheaths of invertebrate nerve fibres have a unique structure that differs from vertebrate myelinated fibres in that the nucleus of Schwann cell is located within the innermost lamina of the myelin sheath (Heuser and Doggenweiler, 1966; Ke Xu and Terakawa, 1999). Roots (1995) suggested that the myelin sheath has evolved independently in chordates, annelids and arthropods. Neverthless, ultrathin sections of $C$. irroratus brain proved the position of Schwan cell nucleus outside the myelin sheath, quite similar to the myelinated nerve fibres of vertebrates (McAlear et al., 1958). In the current investigation, it is possible that the myelin sheath covering the axons acts as an electrical insulator and may provide mechanical support for the axon. It is also suggested that the microtubular sheath surrounding the axon may eliminate the wide gap between the axon and the myelin sheath.

In the present investigation, the SG was found occupying a position between the MI and ME. A more or less similar positioning was reported for the SG in $P$. paucidens (Hisano, 1976), P. serratus (Van Herp et al., 1977), M. rosenbergii (Dietz, 1982), P. stylifera (Nagabhushanam et al., 1986), C. maenas (Dircksen, 1992), P. indicus (Mohamed et al., 1993) and M. ensis, (Gunawardene et al., 2002). On the other hand, the SG was found dorsal to the MI in G. lateralis (Hodge and Chapman, 1958), adjacent to the MI in P. gaimardii (Lake, 1970), in the MT ganglion in Sesarma (Enami, 1951), at the dorsolateral surface of the MT in
Cardisoma carnifex (Weatherby, 1981), on the abaxial side of MT in the crab Charybdis lucifera (Chandy and Kolwalkar, 1985), laterally between the MI and MT regions in $P$. pelagicus (Rajendiran and Vasudevan, 2016), dorsally at the junction of the MI and MT in D. bicristimanus (Nagabhushanam and Sarojini, 1969)

In T. schirnerae, the SG is a deeply stained oval structure. Earlier studies reported different shapes for SG in crustaceans. Enami (1951) distinguished the SG as a triangular structure in Sesarma while flattened ovoid in $P$. gaimardii (Lake, 1970), crescent shaped in P. serratus (Van Herp et al., 1977), ellipsoid in C. carnifex (Weatherby, 1981) and in P. indicus (Mohamed et al., 1993), as a palmate leaf in $M$. rosenbergii (Dietz, 1982). Conversely, in $N$. norvegicus (Giulianini et al., 1998) and P. homarus (Fernandez and Radhakrishnan, 2010), no specific shape could be assigned to the SG.

As reported in the SG of Callinectes sapidus (Andrews et al., 1971) and Homarus gammarus (Castany et al., 1997), seven different types of axonal endings were identified in the SG of $T$. schirnerae. On the contrary, the SG of $G$. lateralis (Bliss and Welsh, 1952; Hodge and Chapman, 1958) and P. paucidens (Hisano, 1976) described four distinct types, five in Procambarus clarkii (Bunt and Ashby, 1967) and Uca pugnax (Silverthorn, 1975) and six in P. borealis (Carlisle, 1959) and C. carnifex (Weatherby, 1981). Histological observations identified six axon terminal types (Rehm, 1959) while fine structural studies demonstrated four types of endings (Smith, 1974; Dircksen, 1992) in C. maenas.

In crustaceans, the number of NSG types varied from two to seven. According to the present study, seven NSG types were identified in the axon terminals of $T$. schirnerae. Similar observations were made in $C$. sapidus (Andrews et al., 1971) and H. gammarus (Castany et al., 1997). However, two 
types of NSGs were identified in $G$. lateralis (Hodge and Chapman, 1958); three in C. maenas (Meusy, 1968); four in Pachygrapsus marmoratus (Bressac, 1976); five in P. clarkii (Bunt and Ashby, 1967) and U. pugnax (Silverthorn, 1975) and six types in C. carnifex (Weatherby, 1981). In agreement with the findings in T. schirnerae, each terminal type contained a single type of NSG in $H$. gammarus (Castany et al., 1997). On the other hand, Andrews et al. (1971) and Dircksen (1992) observed the occurrence of several granule types in a single terminal in C. sapidus and $C$. maenas.

Our observations on the presence of glial cells or supporting cells intermingled with axonal terminals in the SG of T. schirnerae was supported by the reports made in SG of many crustaceans like $O$. virilis (Andrew et al., 1978), G. lateralis (Hodge and Chapman, 1958), C. maenas (Dircksen, 1992), $H$. gammarus (Castany et al., 1997) and $C$. carnifex (Weatherby, 1981). According to Mohamed et al. (1993), glial cells were present in the neurosecretory system of $P$. indicus. In compliance with the findings of Bunt and Ashby (1967) in $P$. clarkii, the glial cells in T. schirnerae were observed with cytoplasmic processes, organelles like mitochondria and ER and glycogen granules. Several authors reported the glial cells as store house of glycogen and the vesicular and granular inclusions in the cytoplasm of glial cells are involved in the nutritive, metabolic and catabolic functioning of neurons (Pentreath, 1989). The presence of glycogen and lipids in invertebrate glial cells was reported by Wigglesworth (1960) and Kuffier and Nichols (1966). The glial cells intermingled with the axonal terminals in the SG of $T$. schirnerae may possibly suggest their involvement in bringing, taking away and exchanging of substances to and fro with the neurons. The presence of glycogen in glial cells of $T$. schirnerae has led to the suggestion that these cells supply energy substrate to the NSCs that can survive without external energy source for several hours.

\section{Conclusions}

Fine structural analysis of the optic ganglia of $T$. schirnerae revealed four ganglionic regions and ten neurosecretory cell types. The neurosecretory cells were characterized by nuclei with unusually dense chromatin and other organelles like Golgi bodies, mitochondria, endoplasmic reticulum, ribosomes and lysosomes and inclusions like clear vesicles, condensing vesicles, dense core vesicles, multivesicular bodies and neurosecretory granules. The sinus gland with seven different terminal types enclosing neurosecretory granules of varying size, shape and density reveal the presence of a number of neurohormones synthesized and secreted by the neurosecretory cells of the optic ganglia in T. schirnerae. Further investigations have to be carried out on the immnocytochemistry of the neurosecretory cell types and contents of the axonal endings to confirm the kinds of neurohormones they carried.

\section{Acknowledgments}

The financial support provided by the Kerala State Council for Science Technology \& Environment (Order No. P 115/2016/KSCSTE dt. 03-05-2016) in carrying out this research is gratefully acknowledged. The authors wish to thank the electron microscope facilities provided by the National Institute of Mental Health and Neurosciences, Bangalore.

\section{Conflict of interests}

The authors declare that they have no conflict of interests. 


\section{References}

Andrew, R. D.; Orchard, I.; Salleudin, S. S. M. Structural re-evaluation of the neurosecretory system in the crayfish eyestalk. Cell and Tissue Research, v. 190, p. 235-246, 1978. http://doi.org/10.1007/ BF00218172

Andrews, P. M.; Copeland, D. E.; Fingerman, M. Ultrastructural study of the neurosecretory granules in the sinus gland of the blue crab, Callinectes sapidus. Zeitschrift für Zellforschung und Mikroskopische Anatomie, v. 113, p.461-471, 1971. http://doi.org/10.1007/BF00325666

Beams, H.W.; Kessel, R. G. The Golgi apparatus: Structure and function. International Review of Cytology, v. 23, p. 209-276, $1968 . \quad$ https://doi.org/ 10.1016/S0074-7696(08)60273-9

Bellon-Humbert, C.; Van Herp, F.; Strolenberg, G. E.; Denucé, J. M. Histological and physiological aspects of the medulla externa X organ, a neurosecretory cell group in the eyestalk of Palaemon serratus Pennant (Crustacea, Decapoda, Natantia). The Biological Bulletin, v. 160 , no. 1, p. 11-30, 1981. http://doi.org/10.2307/1540897

Beltz, B.S. Crustacean neurohormones. In: Beltz, B. S.; Laufer, H.; Downer, R. G. H. (Eds.). Endocrinology of selected invertebrate types. New York: A. R. Liss, 1988. p. 235-258.

Bharathi, A.; Sarojini, N.; Padmaja, M. Comparative study of neurosecretory cells in female Penaeus indicus after unilateral eyestalk ablation. International Journal of Scientific and Research Publications, v. 4, no. 7, p. 1-4, 2014.

Bliss, D. E.; Welsh, J. H. The neurosecretory system of brachyuran Crustacea. The Biological Bulletin, v. 103, p. 157-169, 1952. https://doi.org/10.2307/1538442

Bressac, C. Etude ultrastructurale de la glande du sinus du crabe, Pachygrapsus marmoratus. Comptes Rendus de l'Académie des Sciences - Series D, v. 282, p. 1529-1531, 1976.

Bunt, A. H.; Ashby, E. A. Ultrastructure of the sinus gland of the crayfish Procambarus clarkii. General and Comparative Endocrinology, v. 9, no. 3, p. 334-342, 1967. https://doi.org/10.1016/0016-6480(67) 90027-5

Carlisle, D. B.; Knowles, F. G. W. Endocrine control in crustaceans. London: Cambridge University Press, 1959.

Carlisle, D. B. Note preliminaire sur la structure du systeme neurosecreteur du pedoncle oculaire de Lysmata seticaudata Risso (Crustacea). Comptes Rendus de l'Académie des Sciences - Series D, v. 236, p. 2541-2542, 1953.

Carlisle, D. B. On the sexual biology of Pandalus borealis (Crustacea Decapoda). I. Histology of incretory elements. Journal of the Marine Biological Association of the United Kingdom, v. 38, p. 381-394, 1959. https://doi.org/10.1017/S00253154000061 60

Castany, J.; Van Herp, F.; Charmantier, G.; Trilles, J. P.; Charmantier-Daures, M. Ultrastructural study of the neurosecretory granules and crustacean hyperglycemic hormone $(\mathrm{CHH})$ immunolocalization in the sinus gland of Homarus gammarus. Journal of Crustacean Biology, v. 17, no. 1, p. 6-12, 1997. http://doi.org/10.1163/193724097X 00025

Chandy, J. P.; Kolwalker, D. G. Neurosecretion in the marine crab, Charybdis lucifera. Indian Journal of Marine Science, v. 14, p. 31-34, 1985.

Charmantier, G.; Charmantier-Daures, M.; Van Herp, F. Hormonal regulation of growth and reproduction in crustaceans. In: Fingerman, M.; Nagabhushanam, R.; Thompson, M. F. (Eds.). Endocrinology and reproduction. Enfield, NH: Science Publishers, 1997. v. 1. p. 109-201.

Charmantier-Daures, M.; Segonzac, M. Organ of Bellonci and sinus gland in three decapods from Atlantic hydrothermal vents: Rimicaris exoculata, Chorocaris chacei, and Segonzacia mesatlantica. Journal of Crustacean Biology, v. 18, no. 2, p. 213-223, 1998. http://doi.org/10.2307/1549315

Dietz, R. A. Eyestalk histology and the effects of eyestalk ablation on the gonads of the shrimp, Macrobrachium rosenhergii (De Man). Texas A\&M University, College Station, 1982. (Ph.D. thesis).

Dircksen, H. Fine structure of the neurohemal sinus gland of the shore crab, Carcinus 
maenas, and immuno-electron-microscopic identification of neurosecretory endings according to their neuropeptide contents. Cell and Tissue Research, v. 269, p. 249-266, 1992. http://doi.org/10.1007/ BF00319616

Diwan, A. D.; Nagabhushanam, R. The neurosecretory cells of the central nervous system of the freshwater crab Barytelphusa cunicularis (Westwood 1836). Rivista di Biologia, v. 68, p. 79-99, 1975.

Durand, J. B. Neurosecretory cell types and their neurosecretory activities in the crayfish. The Biological Bulletin, v. 111, p. 62-76, 1956.

Enami, M. The sources and activities of two chromatophorotropic hormones in crabs of the genus Sesarma. II. Histology of incretory elements. Cell and Tissue Research, v. 101, p. 241-258, 1951.

Fernandez, R.; Radhakrishnan, E. V. Classification and mapping of neurosecretory cells in the optic, supraoesophageal and thoracic ganglia of the female spiny lobster Panulirus homarus (Linnaeus, 1758) and their secretory activity during vitellogenesis. Journal of the Marine Biological Association of India, v. 52, no. 2, p. 237-248, 2010.

Fingerman, M.; Nagabhushanam, R.; Sarojini, R. Vertebrate-type hormones in crustaceans: Localization, identification and functional significance. Zoological Science, v. 10, p. 13-29, 1993.

Frasca, J. M.; Parks, V. R. A routine technique for double-staining ultrathin sections using uranyl and lead salts. The Journal of Cell Biology, v. 25, no. 1, p. 157-161, 1965. http://doi.org/10.1083/jcb.25.1.157

Giulianini, P. G.; Smullen, R. P.; Bentley, M. G.; Ferrero, E.A. Cytological and immunocytochemical study of the sinus gland in the Norway lobster Nephrops norvegicus (L.). Invertebrate Reproduction \& Development, v. 33, no. 1, p. 57-68, 1998. http://doi.org/10.1080/07924259.1998.965 2342

Gunawardene, Y. I. N. S.; Tobe, S. S.; Bendena, W. G.; Chow, B. K. C.; Yagi, K. J.; Chan, S.-M. Function and cellular localization of farnesoic acid 0-methyltransferase (FAMeT) in the shrimp, Metapenaeus ensis. European Journal of Biochemistry, v. 269, p. 3587-
3595, 2002. http://doi.org/10.1046/j.14321033.2002.03048.x

Heuser, J. E.; Doggenweiler, C. F. The fine structural organization of nerve fibers, sheaths, and glial cells in the prawn, Palaemonetes vulgaris. Journal of Cell Biology, v. 30, no. 2, p. 381-403, 1966. http://doi.org/10.1083/jcb.30.2.381

Hisano, S. Neurosecretory cell types in the eyestalk of the freshwater prawn Palaemon paucidens. An electron microscopic study. Cell and Tissue Research, v. 166, p. 511520, 1976. http://doi.org/10.1007/ BF00225915

Hisano, S. The eyestalk neurosecretory cell types in the freshwater prawn Palaemon paucidens: I. A light microscopical study. Journal of the Faculty of Science, Hokkaido University, Series 6, Zoology, v. 19, p. 503-514, 1974.

Hodge, M. H.; Chapman, G. B. Some observations on the fine structure of the sinus gland of a land crab Gecarcinus lateralis. The Journal of Biophysical and Biochemical Cytology, v. 4, no. 5, p. 571575, 1958. https://doi.org/10.1083/ jcb.4.5.571

Hopkins, C. R. The fine localization of acid phosphatase in the prolactin cell of the teleost pituitary following the stimulation and inhibition of secretory activity. Tissue and Cell, v. 1, no. 4, p. 653-671, 1969. https://doi.org/10.1016/S0040-8166(69) 80039-X

Hsu, K.; Song, X.; Zhang, T. Microtubular structure of the specific axon wall in the nerve fiber of the shrimp (Penaeus orientalis). Acta Zoologica Sinica, v. 26, p. 220-221, 1980.

Knowles, F. G. W. Crustacean colour change and neurosecretion. Endeavour, v. 14, no. 54, p. 95-104, 1955.

Knowles, F. G. W.; Carlisle, D. B. Endocrine control in the Crustacea. Biological Reviews, v. 81 , p. 396-473, 1956 http://doi.org/ 10.1111/j.1469-185X.1956.tb01556.x

Kuffier, S. W.; Nichols, J. G. The physiology of neuroglial cells. Ergebnisse der Physiologie, Biologischen Chemie und Experimentellen Pharmakologie, v. 57, p. 1-90, 1966. 
Lake, P.S. Histochemical studies of the neurosecretory system of Chirocephalus diaphanus Prevost (Crutacea: Anostraca). General and Comparative Endocrinology, v. 14 , p. 1-15, 1970. http://doi.org/10.1016/ 0016-6480(70)90001-8

Lederis, K. Ultrastructure of the hypothalamo-neurohypophysial system in teleost fishes and isolation of hormone containing granules from the neurohypophysis of the cod (Gadus morrhua). Zeitschrift für Zellforschung und Mikroskopische Anatomie, v. 58, p. 192213, 1962. http://doi.org/10.1007/ BF00320184

Matsumoto, K. Morphological studies on the neurosecretion in crabs. Biological Journal of Okayama University, v. 4, p. 103-176, 1958.

Matsumoto, K. Neurosecretion in the thoracic ganglion of the crab, Eriocheir japonicus. The Biological Bulletin, v. 106, p. 60-68, 1954. https://doi.org/10.2307/1538779

McAlear, J. H.; Milburn, N. S.; Chapman, G. B. The fine structure of Schwann cells, nodes of Ranvier and Schmidt-Lanterman incisures in the central nervous system of the crab, Cancer irroratus. Journal of Ultrastructure Research, v. 2, no. 2, p. 171-176, 1958. https://doi.org/10.1016/S0022-5320(58) 90015-7

Meusy, J.J. Precisions nouvelles sur l'ultrastructure de la glande du sinus d'un Crustace Decapode Brachyoure. Carcinus maenas L. Bulletin de la Société Zoologique de France, v. 93, p. 291-299, 1968.

Mohamed, K. S.; Diwan, A. D. Neuroendocrine regulation of ovarian maturation in the Indian white prawn Penaeus indicus $\mathrm{H}$. Milne Edwards. Aquaculture, v. 98, p. 381-393, 1991. http://doi.org/10.1016/0044-8486 (91)90320-7

Mohamed, K. S.; Vijayan, K. K.; Diwan, A. D. Histomorphology of the neurosecretory system in the Indian white prawn Penaeus indicus $\mathrm{H}$. Milne Edwards. Bulletin of the Institute of Zoology, Academia Sinica, v. 32 , no. 1 , p. $39-53,1993$.

Nagabhushanam, R.; Sarojini, R. Neurosecretion in the central nervous system of the hermit crab, Diogenes bicristimanus. Proceedings of the Indian Academy of Sciences - Section B, v. 69, p. 20-28, 1969.
Nagabhushanam, R.; Sarojini, R.; Joshi, P. K. Observations on the neurosecretory cells on the marine penaeid prawn, Parapenaeopsis stylifera. Journal of Advanced Zoology, v. 7, no. 2, p. 63-70, 1986.

Nakamura, K. Studies on the neurosecretion of the prawn, Penaeus japonicus. I. Positional relationship of the cell groups located on the supra oesophageal and optic ganglion. Memoirs of the Faculty of Fisheries, Kagoshima University, v. 23, p. 175-184, 1974.

Naylor, E.; Smith, G.; Williams, B. G. The role of the eyestalk in the tidal activity rhythm of the shore crab Carcinus maenas (L). Neurobiology of Invertebrates, v. 1971, p. 423-429, 1993.

Nishiitsutsuji-Uwo, J. Fine structure of neurosecretory system in Lepidoptera. Nature, v. 188, p. 953-954, 1960. https://doi.org/10.1038/188953b0

Padmaja, M.; Deecaraman, M.; Jaganathbose, M. T. Study of neurosecretory cells in sand lobster Thenus orientalis of Royapuram Coast-Chennai. World Journal of Fish and Marine Sciences, v. 2, no. 2, p. 82-85, 2010.

Pandey, A. K.; Pandey, S.; Sridar, N.; Singh, S. P. Studies of neurosecretory cells of eyestalk, brain and thoracic ganglia of Metapenaeus dobsoni (Miers, 1878) in relation to ovarian maturation. Journal of Experimental Zoology, v. 18, no. 1, p. 417-428, 2015.

Parameswaran, R. Neurosecretory cells of the central nervous system of the crab, Paratelphusa hydrodromous. Journal of Cell Science, v. 3, no. 37, p. 75-82, 1956.

Pentreath, V.W. Invertebrate glial cells. Comparative Biochemistry and Physiology Part A: Physiology, v. 93, no. 1, p. 77-83, 1989. https://doi.org/10.1016/ 0300-9629(89)90194-1

Potter, D. D. Histology of the neurosecretory system of the blue crab, Callinecres sapidus. The Anatomical Record, v. 120, p. 216, 1954.

Potter, D. D. Observations on the neurosecretory system of portunid crabs. In: Bargmann, W.; Hanstrom, B.; Scharrer, B.; Scharrer, E. (Eds.). Zweites Internationales Symposium über Neurosekretion. Berlin: Springer, 1958. http://doi.org/10.1007/ 978-3-642-53252-8_23 
Rajendiran, S.; Vasudevan, S. Localization and identification of crustacean hyperglycemic hormone producing neurosecretory cells in the eyestalk of blue swimmer crab, Portunus pelagicus. Microscopy Research \& Technique, v. 79, no. 11, p. 1024-1030, 2016. http://doi.org/10.1002/jemt.22737

Rehm, M. Observations on the localisation and chemical constitution of neurosecretory material in nerve terminals in Carcinus maenas. Acta Histochemica, v. 7, p. 88-106, 1959.

Roots, B. I. The evolution of myelinating cells. In: Vernadakis, A.; Roots, B. (Eds.). Neuronglia interrelations during phylogeny: I. Phylogeny and ontogeny of glial cells. Totawa, New Jersey: Humana Press, 1995. p. 223-248.

Shivers, R. R. Fine structure of crayfish optic ganglia. University Kansas Science Bulletin, v. 47, p. 666-733, 1967.

Silverthorn, U. S. Neurosecretion in the sinus gland of the fiddler crab, Uca pugnax. Cell and Tissue Research, v. 165, p. 129-133, 1975. http://doi.org/10.1007/BF00222805

Smith, G. The neurosecretory cells of the optic lobe in Carcinus maenas (L). Cell and Tissue Research, v. 156, no. 3, p. 403-409, 1975. http://doi.org/10.1007/BF00225368

Smith, G. The ultrastructure of the sinus gland of Carcinus maenas (Crustacea: Decapoda). Cell and Tissue Research, v. 155, no. 1, p.117-125, 1974. http://doi.org/10.1007/BF00220288
Upadhyaya, R. K. Correlative cyclic changes in neurosecretory cells and gonads of a freshwater prawn $M$. malcolmsonii $(H$. Milne Edwards) and its fishery in Weinganga River. Bhopal: Berktullah University, 2000. (Thesis of doctorate).

Van Herp, F.; Bellon Humbert, C.; Luub, J. T. M.; Van Wormhoudt, A. A histophysiological study of the eyestalk of Palaemon serratus (Pennant) with special reference to the impact of light and darkness. Archives de Biologie, v. 88, p. 257-278, 1977.

Weatherby, T. M. Ultrastructural study of the sinus gland of the crab, Cardisoma carnifex. Cell and Tissue Research, v. 220, p. 293312, 1981. http://doi.org/10.1007/ BF00210510

Wigglesworth, V.B. The nutrition of the central nervous system in the cockroach Periplaneta Americana L: The role of perineurium and glial cells in the mobilization of reserves. Journal of Experimental Biology, v. 37, no. 3, p. 500$512,1960$.

Xu, H.; Terakawa, S. Fenestration nodes and the wide submyelinic space form the basis for the unusually fast impulse conduction of shrimp myelinated axons. Journal of Experimental Biology, v. 202, p. 1979-1989, 1999. 